\title{
Will prohibiting the use of physical punishment reduce child abuse deaths among New Zealand children?
}

\author{
Sophie Trevathan and Lynne Briggs
}

Sophie Trevathan carried out this research while an MSW student at the Department of Social Work and Community Development, University of Otago, New Zealand. Sophie was employed as a social worker by New Zealand Child, Youth and Family Service while completing her MSW. The impetus for her research was driven by what she perceived as the ongoing psychological effects of child abuse on young, vulnerable people. She currently works in Italy teaching English to children, but is planning to resume her career in social work in Ireland in 2009.

Dr Lynne Briggs is a Senior Lecturer at the Department of Social Work and Community Development, University of Otago, New Zealand. Lynne supervised Sophie's research. She holds a joint clinical position with the University of Otago as a Senior Lecturer and the Canterbury District Health Board as a Clinical Leader of the Refugee and Migrant Mental Health Service.

\section{Abstract}

The Amendment Act (Crimes (Substituted Section 59) Amendment Act, 2007) came into force on 22 June 2007. The changes in the Act amended the right of parents to use force by way of correction toward a child. The purpose of this amendment was to provide children with a safer and more secure environment to live in that is free from violence. Such a move also has the potential to provide a clearer mandate for social workers in regard to issues of child safety. While planned, reviews to determine how effective the amendment has been have not yet been undertaken.

This paper presents some key findings from a larger study exploring the issue of child abuse deaths in New Zealand. In doing so a comparison of legislation and policy between New Zealand and Sweden is presented. Sweden was used as the main focus for this comparison as it introduced a ban on use of corporal punishment of children in 1979.

\section{Introduction}

As a signatory to the United Nations Committee on the Rights of the Child (UNCROC) adherence to the Convention and Government actions taken to improve the rights of children in New Zealand are reviewed every five years. While the issue of corporal punishment is raised in many of the 54 articles contained in UNCROC, prior to the passing of 'the Amendment Act (2007)' Section 59 of the New Zealand Crimes Act (1961) New Zealand was in direct violation of Article 19. This violation was reflected in the 1995 and 2000 UNCROC reviews where New Zealand's failure to amend this Act was seen as being inconsistent with the Convention (Taylor, 2004). 
Internationally a very different picture had emerged. In Sweden the rights of children to physical and social health had been a concern for some time. In 1979 it was the first country in the world to abolish the right of its citizens to use physical punishment to discipline children. As Durrant (2000) notes, this move appears to have led to a decrease in the number of Swedish children dying from abusive injuries.

In contrast to Sweden (and other rich nations) New Zealand still has an unacceptable number of children dying from child abuse. The Ministry of Social Development (2005, p. 128) noted that 'child maltreatment death almost doubled between the mid to late-1980s, with very little change since'. Between 1996 and 2000, 49 children under the age of 15 years had died in New Zealand from child abuse (The Ministry of Social Development, 2005). While a UNICEF (2003) report comparing child deaths across countries showed that the annual average child maltreatment death rate of children under the age of 15 years in New Zealand had declined from 1.2 per 100,000 a year to 0.9 per 100,000 , the rate of child abuse deaths is an issue that needed to be addressed.

At the time of undertaking the Trevathan (2007) study New Zealand was still debating repealing Section 59 of the Crimes Act (1961). In May 2007, Section 59 of the Crimes Act (1961) was amended by an overwhelming majority in Parliament and the law entered into force in June 2007. The new law means parents who assault children no longer have the defence of 'reasonable force'.

The amendment also makes it obligatory for social workers to follow the law rather than making decisions based on subjective understandings. Thus, it provides a solid base for making the difficult professional judgments that care and protection social workers are required to make every day in assessing children at risk and in making safe decisions that are in keeping with good practice guidelines. It also offers both social workers and families a basis for learning new techniques for disciplining children, thereby ensuring all families are treated more equally.

Despite the amendment the definition of 'reasonable force' remains unclear and still leaves children at risk of child abuse and potential death through maltreatment. Taking the above into account the overall aim of this paper is to examine the similarities and differences between New Zealand's and Sweden's care and protection policies. Whether the decision taken by the New Zealand Government to partially implement a ban on the use of physical punishment of children is enough to lower the rate of child abuse deaths is also considered.

\section{Method}

A major aim of the Trevathan (2007) study was to examine and consider the similarities and differences between New Zealand's and Sweden's care and protection policies to determine if:

- The banning of physical punishment assisted in lowering the rate of child abuse in Sweden.

- The lower number of child abuse deaths can be attributed to changes in care and protection policies or accompanying Acts in Sweden. 
- Such deaths were due to other factors, and if so, what those factors might be.

Given the aims of this study mixed methods were considered the most appropriate methodology. While care and protection acts in New Zealand and Sweden were the two main units selected for analysis, what happens in other countries was also briefly explored. Content analysis was used to extract the information contained in the care and protection acts for each country and manifest coding was used to code the information.

As the information was collected important factors in the care and protection of children began to emerge. The information was then coded into the themes, compared and contrasted. This allowed for the qualitative data to be transformed into quantitative variables that allowed for further analysis to be undertaken. Where appropriate, frequency tables were drawn up to present the findings.

\section{New Zealand Children, Young Persons and Their Families Act}

The implementation of the Children, Young Persons and Their Families Act (CYPF Act, 1989) revolutionised care and protection proceedings in New Zealand and attracted international attention. The concept of the child being 'paramount' and the inclusion of cultural values were key factors in the final Act. As Tapp \& Taylor (2002) note, the philosophical belief that given the power, information and the necessary resources to do so, families could make safe and appropriate decisions for their children, led to the formal development of Family Group Conferencing (FGC). Connolly (2005, p. 536) also argues that the promotion of family autonomy in a solution-focused environment is at the heart of FGC as it is here that family members, together with professionals, make decisions regarding a child or children in need. Giving priority to keeping children within their family or whanau also changed the ways in which social workers could intervene in family life.

Despite this Act, child abuse and child abuse deaths in New Zealand have continued to occur. Doolan (2004), when investigating 91 child homicides (aged 0-14 years) occurring between 1991 and 2000 found that 90\% were killed by someone known to them, 81\% of whom were family members; $6 \%$ were killed by strangers, while in the remaining $4 \%$ the relationship of the perpetrator to the child was unknown.

A report by the Ministry of Social Development (2006) shows that between 1993 and 2003 the average annual rate of child abuse deaths for children under the age of 12 months was 4.6 deaths per 100,000 . This rate is three times higher than the rate shown for 1-4 year olds (1.3 per 100,000$)$ and eight times higher than the rate for $5-14$ year olds $(0.6$ per 100,000$)$. Of all the children killed over that period in total $30 \%$ were under the age of 12 months and $63 \%$ were less than five years old.

The CYPF Act (1989) sets out to protect children and young people in New Zealand whereas the New Zealand Crimes Act (1961), until the passing of the Amendment Act in 2007, allowed parents to use reasonable force to discipline a child - thus contradicting what the CYF Act is trying to provide. 


\section{Sweden}

Sweden has two acts and one code that are concerned with the care and protection of children. The first is the Social Services Act (1982) (Socialtjanstlagen, SoL). This requires voluntary participation by parents and contains two voluntary preventative measures: the assigning of a contact person to provide the family with support when needed and placing the child outside the home. As the main aim of the Act is to keep the child within the family, interventions are focused on improving interactions between parents and their children (Khoo, Nygren \& Hyvanen, 2002).

The second act, the Special Provisions for Care of Young Persons Act (1990) (Lagen med sarskilda bestammelser om vard av unga, LVU), is similar to the New Zealand CYF Act (1989). Measures taken under this Act are compulsory with three possible interventions: short-term out-of-home care, primarily during investigation; long-term or permanent outof-home care; assignment of a contact person. Such interventions would only be undertaken if the child's wellbeing is deemed to be at serious risk (Durrant, 2000, p. 20).

It is interesting to note that Sweden, rather than placing the 1979 ban of physical punishment toward children in either act, implemented it through their 'Parenthood and Guardianship Code'. This was achieved by including the following statement in the Code: 'The law states: Children are entitled to care, security and a good upbringing; Children are to be treated with respect for their person and individuality and may not be subjected to physical punishment or other injurious or humiliating treatment' (Durrant, 2004, p. 25). A further clause was added stating explicitly that '... children may not be punished by blows, beatings, boxing of the ears or other similar means, and that children may not, for any other reason or cause, be subjected to acts of physical or mental coercion' (Ritchie \& Ritchie, 1981, p. 130). This new legislation made it explicit that in Sweden the use of physical punishment to discipline children would not be tolerated.

The placing of the new law in the Parents Code rather than the Penal Code makes it clear that the intent was to prevent child abuse rather than to criminalise parents. Such a move upheld the 'rights of children' rather than imposing criminal penalties. Thus, while providing a strategy aimed at educating and helping parents, a new culture was being created where children are identified as people and right-holders (Gallaway, 1999, p. 3). In this way, the State, working in partnership with families, ensures that children are seen as a societal responsibility rather than just the responsibility of parents.

The three main reasons for introducing the Swedish ban included changing attitudes about physical punishment towards children, and setting standards for what was, and what was not, acceptable punishment by parents and professionals. It was also envisaged that early identification of abuse meant early intervention by social workers who, in turn, would assist in decreasing rates of severe child abuse and child abuse deaths (Ross, 2002).

Accompanying this important change was the 'parent education campaign' that occurred alongside the introduction of 1979 law. In Sweden the Government launched a campaign that included sending information about the new law, and other alternatives to smacking, to every household with a young child (Ross, 2002). 
In 1981 the Swedish Government reported that' ...99\% of Swedes were now familiar with the law'. Ross $(2002$, p. 4) argues '...this level is unmatched in any other study of knowledge in regard to law in industrialised societies'. Sweden has continued to educate its society about this law, it happens in the schools from ninth grade onwards and with all new parents.

\section{Similarities and differences in care and protection legislation}

As noted above, the first and foremost difference between Sweden and New Zealand is the issue of physical punishment. Furthermore, in Sweden the ban is contained within the Parenthood and Guardianship Code, while in New Zealand the issue of physical punishment is contained within Section 59 of the Crimes Act (1961). Prior to the passing of the 2007 Amendment, Section 59 of the New Zealand Crimes Act 1961 stated:

(1) Every parent of a child and, subject to subsection (3) of this section, every person in place of the parent of a child is justified in using force by way of correction towards the child, if the force used is reasonable in the circumstances.

(2) The reasonableness of the force used is a question of fact.

(3) Nothing in subsection (1) of this section justifies the use of force towards a child in contravention of section 139A of the Education Act 1989.

Whereas the Swedish Parenthood and Guardianship Code states:

(1) Children are entitled to care, security and a good upbringing.

(2) Children are to be treated with respect for their person and individuality.

(3) Children may not be subjected to physical punishment or other injurious or humiliating treatment.

Further comparisons between the New Zealand CYF Act (1989) and translated versions of Sweden's Care of Young Persons Act 1990 and Social Services Act (2001) were made. The results are presented in Table one below and show the age of children and young people coming under care and protection acts in both New Zealand and Sweden is similar. Both countries offer a definition for a child or young person in need of care and protection; an appointed Commissioner for Children; allowance for State removal of children where necessary and the ability of social workers to obtain a medical examination if required.

Under the law in New Zealand if a child is found to be in need of care and/ or protection then that child will be referred for an FGC. It is the social worker involved (in consultation with their supervisor) that is responsible for the decisions and the care of the child or young person. In Sweden, it appears a committee is held responsible. Furthermore, in New Zealand social workers must consult each case with a care and protection resource panel. In contrast to this Sweden has a social welfare committee but as consultancy is its main role it only partially exists. A major difference in the two countries' policies is that in Sweden it is mandatory to report child abuse, whereas in New Zealand it is not. Instead people are encouraged to do so. 
The comparison also showed both countries have a policy in regard to permanency, paramountcy and minimal intervention. Both countries recognise that children and young people have different needs, that children require protection and that their rights need to be upheld. Although timeliness and children's needs feature in both Acts, in New Zealand cases are prioritised according to the seriousness of the case. This differs in Sweden where investigations are undertaken immediately regardless of need. While attention about the use of alcohol and drugs by children, and around children, is clearly contained in the Swedish Act it is not mentioned in the New Zealand Act.

Table one. Main principles of the care and protection legislation in New Zealand and Sweden.

\section{Protective factors for children}

Applies to children/young people 17 years and younger Applies to children/young people 18 years and younger Social worker responsible for decisions and care arrangements Social welfare committee responsible for decisions and care arrangements

Care and Protection Resource Panel

Commissioner for Children

Definition of a child/young person being abused

Any person may report ill-treatment

Mandatory reporting

Immediate removal of child if necessary

Medical examinations

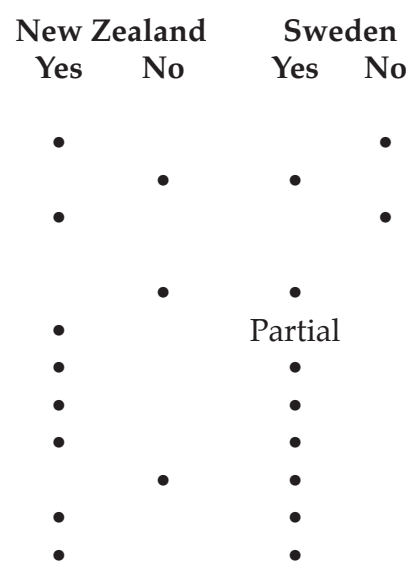

Involving families, maintaining family relationships and perceiving the family as the primary caregiver of children are also key features in both Acts. The main difference is the concept of family group conferencing which is specific to the New Zealand decision-making process. In contrast to this, in Sweden, the first step following notification of child abuse is the voluntary assignment of a contact person to the family, with parents making a monetary contribution to the services provided. Maintaining close cooperation with the family and obtaining voluntary agreement about care plans is emphasised more in Swedish legislation than in New Zealand's.

The study also found many similarities between court proceedings in Sweden and New Zealand, including: declaring that a child or young person is in need of care and protection; the court's ability to place the child in custody until a more permanent decision is made; the establishment of residential homes; returning a child to its parents at any stage and the appointment of a barrister or lay advocate for the child to whom appeals can be addressed.

The main differences include: New Zealand's ability to place a restraining order against someone; support orders that ensure the child is cared for by someone and that can also be used to obtain different services and resources for the child; a requirement for certain people to be present in court; that joint hearings may take place; the listing of people entitled to be in court; that the child or young person may give evidence in private; that mediation conferences can take place and provision is made for cultural services to take over custody. In Sweden if a care arrangement is infringed the person may incur a fine. 
Similarities include the court's ability to order and fund counselling, assistance services, medical, psychiatric and psychological reports. In New Zealand the court has the right to request and obtain important documents and specific cultural reports. It can also approve other organisations that are not included in the Act to provide services to the family. In Sweden organisations are expected to cooperate with families.

\section{International perspectives}

As the scale and severity of the problem of child abuse has increased Governments throughout the world have been compelled to face issues of violence towards children.

A review of international literature revealed 13 countries have completely abolished physical punishment of children in an attempt to reduce child abuse. As Taylor (2004) noted, many countries (Sweden, 1979; Finland, 1983; Denmark, initially in 1985 then more explicitly in 1997; Norway, 1987; Austria, 1989; Cyprus, 1994; Latvia, 1998; Croatia, 1999; Israel, 2000; Germany, 2000; Iceland, 2003; Ukraine, 2004 and Romania, 2004) began by prohibiting corporal punishment in schools and then later removed parental rights to physically punish children.

A UNICEF (2003) report showed that during the 1990s, New Zealand had an average child maltreatment death rate of 1.2 per 100,000 per year of the child population aged under 15 years of age - the third highest out of 27 countries. This same study showed that Spain, Greece, Italy and Ireland have extremely low rates of child abuse deaths (less than 0.2 deaths for every 100,000 children) compared to both Hungary and New Zealand where death rates (1.2 deaths for every 100,000 children) are approximately six times higher than countries with low death rates. In Mexico and the United States of America child death rates are more than 10 times higher than in countries with low death rates. In comparison to Sweden (rated ninth in this sample), New Zealand was rated 25th out of 27 countries (UNICEF, 2003).

After considering the differing definitions of child maltreatment and the way notifications were recorded, UNICEF (2003) revised the findings to include child deaths from undetermined causes. Thus, while there was little change in child death rates for the majority of the countries, child death rates in the Czech Republic, Slovak Republic and United Kingdom more than doubled when deaths from undetermined causes were added to their totals. In France the rate almost trebled, Portugal was eight times higher, which positioned it just below the rates for the United States of America and Mexico (UNICEF, 2003).

Of note, Sweden went from ninth position in the previous table to seventh position in the revised table and New Zealand from 25th position to 22nd position for the revised table. However, while decreasing in country ranking the actual numbers of child deaths had increased in New Zealand from 1.2 to 1.3 deaths for every 100,000 children (Doolan, 2004).

While acknowledging that differing methodologies can make direct international comparisons difficult, such figures do give a measure of how New Zealand stands in comparison to other countries. Thus, in order to compare child deaths just between Sweden and New Zealand, statistics collated over a 22-year period by several researchers (Kotch, Chalmers, Fanslow, Marshall, \& Langley, 1993; Doolan, 2004; Durrant, 2000) were explored. This investigation showed that while child death rates in both countries had remained much the 
same, in New Zealand the rate of child deaths remained at least twice as high as that of Sweden's.

\section{The debate: Section 59 of the New Zealand Crimes Act (1961)}

The debate around banning the use of physical punishment in New Zealand 'reflects differing views of the desirable distribution of power in the family, the position of the child in society and the role of the State' (Durrant \& Olsen, 1997, p. 443). Generally the use of physical punishment is based on values, religious beliefs, government, social policy and laws (Benjet \& Kazdin, 2003). Lansdown (2001) states the social and legal endorsement of hitting children is one of the most symbolic indications of the low status of children in our society.

As in Sweden, legislative change is often required to bring about attitudinal change with the aim of protecting children from child abuse and child abuse deaths. Other acts, for example, the emergence of the ground-breaking CYF Act (1989) and international law such as UNCROC also reflect attitudinal change and assist in addressing the rights of children.

The question debated by the New Zealand Government was whether to amend the Act to include a definition of 'reasonable force' or to make a clear statement to all New Zealanders by completely banning the use of physical punishment. The Government of the time looked to different countries to see how they have dealt with the issue; including Sweden and other countries that have defined reasonable force clearly in an endeavour to better protect children without fully banning physical punishment (Dobbs, 2005).

The issue was widely debated in Parliament with some MPs (e.g., the Hon John Tamihere, Minister of Youth Affairs) wishing to retain 'reasonable force' as a defence. Others, e.g. Sue Bradford MP and the Green Party, wished to repeal it. Some politicians wanted 'reasonableness' to be defined more clearly, others wanted the law reviewed after the evaluation of a public education strategy, and others saw the repeal as inevitable (Taylor, 2004). More importantly, Helen Clark, the then Prime Minister of New Zealand, repeatedly reiterated her support for repealing Section 59. Sue Bradford's Private Members' Bill gained attention within this debate. Bradford believed the issue of physical punishment is deep within the psyche of this country and wanted this section of the Act fully repealed. Bradford believed that rather than the 'gentle smack' being an issue, it is parents who are able to use 'reasonable force' as a defence and thus avoid being penalised by the court for gross abuse.

\section{The process to date}

The Crimes (Abolition of Force as a Justification for Child Discipline) Amendment Bill was introduced into Parliament in June, 2005 (Bradford, 2005). Rather than fully repealing the use of physical punishment, this legislation allowed parents to use reasonable force (such as restraining) to stop a child from hurting themselves or others, and to prevent disruptive behaviour, such as refusing to leave a store (NZPA, 22 February, 2007). A further amendment was added to allow police to use their discretion when dealing with trivial offences in regard to prosecution. This amendment did not change the Bill, but appeased members of the Government and the public who believed they could be prosecuted for minor offences. 
At the same time it was also agreed that a review of how effective the new law has been would be undertaken in 2009 (NZPA, 3 May, 2007). Thus after two years of polarised debate the Amendment Bill was passed by 113 votes to 8 (NZPA, 17 May, 2007). Section 59 was substituted with:

59 Parental Control:

(1) Every parent of a child and every person in the place of a parent of the child is justified in using force if the force used is reasonable in the circumstances and is for the purpose of -

(a) preventing or minimising harm to the child or another person; or

(b) preventing the child from engaging or continuing to engage in conduct that amounts to a criminal offence; or

(c) preventing the child from engaging or continuing to engage in offensive or disruptive behaviour; or

(d) performing the normal daily tasks that are incidental to good care and parenting

(2) Nothing in subsection (1) or in any rule of common law justifies the use of force for the purpose of correction

(3) Subsection (2) prevails over subsection (1)

(4) To avoid doubt, it is affirmed that the Police have the discretion not to prosecute complaints against a parent of a child or person in the place of a parent of child in relation to an offence involving the use of force against a child, where the offence is considered to be so inconsequential that there is no public interest in proceeding with a prosecution

More importantly, Bradford called for Government to develop an education campaign to educate parents about alternative ways to discipline children (NZPA, 17 May, 2007). Thus, overall, the intentions to repeal section 59 of the Crimes Act 1961 were 'to uphold the rights of children to safety and physical integrity; to set clear standards of non-physical discipline; to improve the protection of the children whose cases involved severe enough assault to go to court and to move New Zealand towards change in its culture in regard to the use of physical discipline' (Wood, 2006, pp. 2-3).

\section{Discussion}

Despite the inherent difficulties in both interpretation and comparison across countries, when attempting to ascertain child homicides, reported child abuse deaths are seen as a gauge of the level of violence experienced by children in a society. Sweden is perceived as a world leader in reducing child abuse deaths. Since introducing the Swedish ban, 23 other countries have now also legally banned the use of physical punishment towards children (UNICEF, 2008). While a review of the literature confirmed that generally the overall rates of child deaths in rich nations are on the decline, this does not appear to have happened in New Zealand where rates have remained consistently higher than rates in Sweden.

In a study such as this it is difficult to ascertain whether the decrease in child abuse deaths in Sweden (or other countries) is due to the banning of corporal punishment or other changes in society. For example, in Sweden the rights of children and child welfare is regarded as being of utmost importance and are perceived as a societal responsibility rather than just that of the parents. Alongside the ban, many other changes had occurred over several decades. This in turn led to an improvement in the lives and well-being of children with the emphasis of these changes being focused on prevention rather than intervention. 
A major difference between New Zealand and Sweden is the promotion of an effective parent education campaign for all that educates parents in regard to strategies for disciplining children. The New Zealand Parliament also agreed to review the effect this new law will have had within the next two years of implementation. Neither a parent education programme nor the review have been undertaken to date.

In regard to social work practice the care and protection of children is an increasingly complex area that contains several overlapping laws and policies that guide social workers who are charged with this task. A prime example is the CYF Act (1989) which reflects a commitment to family empowerment and family participation in decision making about children. Another example is the Crimes (Substituted Section 59) Amendment Act (2007). While the law can provide the framework, for social work practice the actual decision making is also influenced by professional knowledge and theory. Thus, although it is the Police who will ultimately prosecute offenders, in the first instance social workers will make the decision as to whether the law has been breached.

It is of course, the hope of the social work profession that prohibiting the use of physical punishment will reduce child abuse deaths among New Zealand children. However, whether the new law has had an impact or not is yet unknown. Thus, the findings and outcomes of the proposed reviews are awaited.

\section{Conclusion}

Just prior to completion of the Trevathan (2007) study an Amendment to Section 59 of New Zealand's Crimes Act (1961) was made. The new law still uses the terms 'justified' and 'reasonable' but the circumstances in which physical punishment can be used have been more clearly defined under the new law. Thus, finally, New Zealand has met its international obligations to UNCROC. However, the question as to whether this change is enough to lower the rate of child abuse deaths remains unanswered at this point in time.

\section{References}

Benjet, C., \& Kazdin, A.E. (2003). Spanking children: The controversies, findings and new directions. Clinical Psychology Review, 23(2), 197-224.

Bradford, S. (2005). Crimes (Abolition of Force as a Justification for Child Discipline) Amendment Bill 2005. Bills Digest No. 1278, Wellington: New Zealand Parliamentary Library.

Connolly, M. (2005). Fifteen years of Family Group Conferencing: Coordinators talk about their experiences in Aotearoa New Zealand. British Journal of Social Work, 36(4), 523-540.

Dobbs, T. (2005) Children's insights into family discipline. A thesis submitted for the degree of Master of Arts (Childhood and Youth Studies) of the University of Otago, Children's Issues Centre, Dunedin, New Zealand.

Doolan, M. (2004). Child death by homicide: An examination of incidence in New Zealand 1991-2000. Te Awatea Review, 2(1), 7-10.

Durrant, J.E., \& Olsen, G.M. (1997). Parenting and public policy. Contextualizing the Swedish corporal punishment ban. Journal of Social Welfare and Family Law, 19(4), 443-461.

Durrant, J.E. (2000). A generation without smacking: The impact of Sweden's ban on physical punishment. London: Save the Children.

Durrant, J.E. (2004). Whose body is it anyway? Physical punishment, children's rights and parental responsibility. Children Issues, 8(2), 23-26.

Gallaway, A. (1999). A submission seeking to repeal section 59 of the New Zealand Crimes Act 1961. Article Collection 2001: Family Issues. Children's Issues Centre, University of Otago.

Khoo, E., Nygren, L., \& Hyvonen, U. (2002). Child welfare or child protection. A comparative study of social intervention in child maltreatment in Canada and Sweden. In M. Hill, A. Stafford, \& P.M. Lister (Eds.). International perspectives on child protection. Report of a seminar held on 20 March 2002. Glasgow: Centre for the Child and Society. 
Kotch, J., Chalmers, D., Fanslow, J., Marshall, S., \& Langley, J. (1993). Morbidity and death due to child abuse in New Zealand. Child Abuse and Neglect, 17, 233-247.

Lansdown, G. (2001). Children's rights: A second chance. London: International Save the Children Alliance.

Ministry of Health and Social Affairs, Sweden. (2005). Social Services Act: SFS 2001, Promulgated: 7 June, with amendments up to and including SFS 2004:851. Date of translation: March 2005. Sweden: Ministry of Health and Social Affairs.

Ministry of Health and Social Affairs, Sweden. (2005). The Care of Young Persons Act: SFS 1990, Promulgated: 8 March 1990 with amendments up to and including SFS 2003:420. Date of translation: March 2005. Sweden: Ministry of Health and Social Affairs.

Ministry of Social Development. (2005). The Social Report 2005. Wellington: Ministry of Social Development.

Ministry of Social Development. (2006). Children at increased risk of death from maltreatment and strategies for prevention. Ministry of Social Development.

Ministry of Youth Affairs. (2000). Children in New Zealand, United Nations Convention of the Rights of the Child: Second Periodic Report of New Zealand, December 2000. Wellington, Ministry of Youth Affairs.

NZPA. (2007, February 22). Discipline Bill passes second reading. Otago Daily Times.

NZPA. (2007, May 3). Amendment clears way for Bill. Otago Daily Times.

NZPA. (2007, May 17). Big vote puts Smacking Bill into law. Otago Daily Times.

Ritchie, J., \& Ritchie, J. (1981). Spare the rod. North Sydney: George Allen and Unwin Australia.

Ross, G. (2002). The physical chastisement of children: Lessons learned from Sweden and Germany. The Scottish Parliament: The Information Centre.

Tapp, P., \& Taylor, N. (2002). Protecting the family. In M. Henaghan \& B. Atkin (Eds.). Family law policy in New Zealand (2nd ed.). Wellington: Lexis Nexis Butterworths.

Taylor, N. (2004). International law. In A.B. Smith, M.M. Gollop, N.J. Taylor, \& K.A. Marshall (Eds.). The discipline and guidance of children: Messages from research, a review of research literature for the Office of the Children's Commissioner by the Children's Issues Centre. Dunedin: University of Otago, Children's Issues Centre, Commissioner for the Children.

The New Zealand Children, Young Persons and Their Families Act. (1989).

The New Zealand Crimes Act. (1961). Section 59.

The Amendment Act (The Crimes (Substituted Section 59) Amendment Act, 2007)

Trevathan, S. (2007). Stopping the hurt: Laws prohibiting the use of physical punishment could reduce the rate of child abuse deaths amongst New Zealand children. MSW thesis, University of Otago, Dunedin.

UNICEF. (2008). The Crimes (Substituted Section 59) Amendment Act - Media Kit. Retrieved on 31 August, 2008, from http:/ / www.unicef.org.nz/speaking-out/nz-children/April_2008_media_kit.pdf.

UNICEF. (2003). A league table of child maltreatment deaths in rich nations. Innocenti Report Card, Issue No.5, Florence: UNICEF Innocenti Research Centre. Retrieved June 18, 2005, from http: / / www.unicef-icdc.org.

Wood, B. (2006). Article on repeal of Section 59 Crimes Act 1961. Retrieved from http: / / www.converge.org.nz / pma / subsec59.htm, on 19 April 2006. 